\title{
Role of Physiotherapy in Hospitalised Patients of COVID-19 disease
}

\author{
Kumar Bharty S. ${ }^{1}$, Kishore Bhargava J. ${ }^{2}$, Prakash B. ${ }^{3}$, Patel V. ${ }^{4}$, Jain A. ${ }^{\mathbf{5}}$, Khatri S. ${ }^{\mathbf{*}}$ \\ DOI: https://doi.org/10.17511/ijmrr.2021.i03.04
}

\footnotetext{
1 Sanjay Kumar Bharty, MBBS DNB, Associate professor, ${ }^{2}$ Jitendra Kishore Bhargava, MBBS DTCD MD, professor Director, 3 Brahma Prakash, MBBS DNB, Associate professor, ${ }^{4}$ Vikas Patel, MBBS MD, Assistant professor, ${ }^{\mathbf{5}}$ Avinash Jain, MBBS MD, Assistant professor, ${ }^{*}$ Sumit Khatri, MBBS MD, Senior Resident; all authors are affiliated with the Department of Respiratory Medicine, SEPM, NSCB Medical college, Jabalpur, Madhya Pradesh, India.
}

Introduction: Respiratory physiotherapy is one of the therapeutic methods in various respiratory viral infections. Breathing exercises with other interventions, could enhance the total lung capacity and symptom alleviation in patients with virus-related acute respiratory distress syndrome (ARDS). Aim: To study the clinical evaluation of the role of physiotherapy in hospitalised patients of covid-19 diseases. Method: This was an Observational (prospective, cross-sectional) study. 187 patients were recruited and diagnosed as COVID-19 as per RTPCR at NSCB Medical College, Jabalpur (MP). Patients were randomised into the physiotherapy group and controlled group. Patients in the physiotherapy group were undergone positional changes, prone ventilation, Breathing exercise, Resistive training, Passive joint motion, Muscle stretching, Bedside standing training, endurance exercise by a specialized physiotherapist. Mean cough severity index, MMRC grade, respiration rate and peripheral blood saturation were recorded before and after intervention and compared with the controlled group. Result: There was significant improvement found in MMRC grade and respiration rate after physical therapy in the physiotherapy group ( $p$-value $<0.05$ ). Exertional dyspnoea and cough severity index significant deceased in physiotherapy group. The positive change was found in peripheral blood saturation. There was decreased in hospitalization stay in the physiotherapy group as compared to the controlled group. Conclusion: Our study revealed the positive effect of physiotherapy on covid-19 disease in terms of symptoms and hospitalization duration among the physiotherapy group. Physiotherapy exerts a beneficial role in the management of the covid-19 disease.

Keywords: COVID-19, Corona Virus Disease 2019, Respiratory Physiotherapy, Breathing exercise, Blood saturation, Hospitalization stay

\section{Corresponding Author}

Sumit Khatri, MBBS MD, Senior Resident, Department of Respiratory Medicine, SEPM, NSCB Medical college, Jabalpur, Madhya Pradesh, India. Email: Jimmyjn6@gmail.com

\section{How to Cite this Article}

Bharty SK, Bhargava JK, Prakash B, Patel V, Jain A, Khatri S. Role of Physiotherapy in Hospitalised Patients of COVID-19 disease. Int J Med Res Rev. 2021;9(3):154-159.

Available From

https://ijmrr.medresearch.in/index.php/ijmrr/article/ view/1284
To Browse

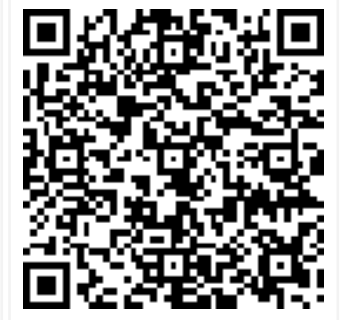

Manuscript Received 2021-05-07

Conflict of Interest No
Review Round 1 2021-05-17

Funding

Nil

Review Round 2
2021-05-29
Ethical Approval
Yes

Review Round 3

Accepted 2021-06-06

Plagiarism X-checker $7 \%$

(C) 2021 by Sanjay Kumar Bharty, Jitendra Kishore Bhargava, Brahma Prakash, Vikas Patel, Avinash Jain, Sumit Khatri and Published by Siddharth Health Research and Social Welfare Society. This is an Open Access article licensed under a Creative Commons Attribution 4.0 International License https://creativecommons.org/licenses/by/4.0/ unported [CC BY 4.0]. 


\section{Introduction}

Respiratory physiotherapy is one of the therapeutic methods in various respiratory viral infections. Breathing exercises with other interventions, could enhance the total lung capacity and symptom alleviation in patients with virus-related acute respiratory distress syndrome (ARDS). Patient who progresses to severe disease showed peripheral and posterior lung lesion and these patient require admission in ICU therefore they are more prone to a complication during and after disease. Therefore the main role of physiotherapy is to limit the severity of ICU acquired weakness and promote rapid functional recovery [1]. Chest physiotherapy technique might help the improvement in airway clearance and lung capacity and reduction of breathing-related work during active disease [2]. Hsieh MJ et al revealed that pulmonary physiotherapy help in the recovery of pulmonary function and decrease hospital stay and improve quality of life in survivors of viral related acute respiratory distress syndrome[3]. It may the prevention of disabilities acquired during hospitalization in ICU and resulting from infection. The chest physiotherapy support both a prophylactic and therapeutic strategy for the covid-19 disease. A key component in the exercise program to restore covid-19 patients' physical fitness. Physiotherapy may be indicated if patients with COVID-19 present with copious airway secretions that they are unable to clear independently. Apart from that, high-risk patients eg. With existing comorbidities that may be associated with hypersecretion or ineffective cough (eg, neuromuscular disease, respiratory disease and cystic fibrosis), ventilated patients who have inadequate airway clearance, prone lying patients and patients who suffer from ICU acquired weakness may also require physiotherapy, as all these conditions may worsen their morbidity and mortality. The primary aim of this study was to evaluate the effectiveness of chest physiotherapy on Covid-19 patients in terms of clinical and hospital stay.

\section{Materials and Methods}

Setting: This study was conducted at NSCB Medical College, Jabalpur (Madhya Pradesh).

Duration: May 2020 to September 2020

Type of study: Observational (prospective, crosssectional) study.
Sample size: 187 patients were admitted with a diagnosis of pneumonia of covid-19 disease at NSCB Medical College, Jabalpur and they are observed for this study.

Inclusion Criteria: All RT-PCR positive for COVID19 patients above 18 years of age admitted at NSCB Medical College, Jabalpur Madhya Pradesh in the study period.

\section{Exclusion Criteria:}

- All RT-PCR negative for COVID-19 patients.

- A haemodynamically unstable patient (altered heart rate and blood pressure)

- The patient had a musculoskeletal disease.

- Pregnant and children patients.

Methodology: Patients were divided into two groups, one is the Physiotherapy group and the second is the Control group(Figure-1). In the physiotherapy group patient is taken physiotherapy interventions by physiotherapist along with general and specific treatment of COVID-19. Physiotherapy intervention has been given according to a comprehensive assessment of the patient and the patient's tailored therapies. The control group received educational session and general exercises.

While patients in the physiotherapy group completed an exercise program provided and monitored by the physiotherapist for 1 to 1.5 hour per session twice a day for 15 days. They were instructed to continue exercise training and ensure that they had adequate training effects. The physiotherapist provided a session of the following exercise according to the compliance of patients in the physiotherapy group.

Figure-1: Representing Randomisation of the patient.

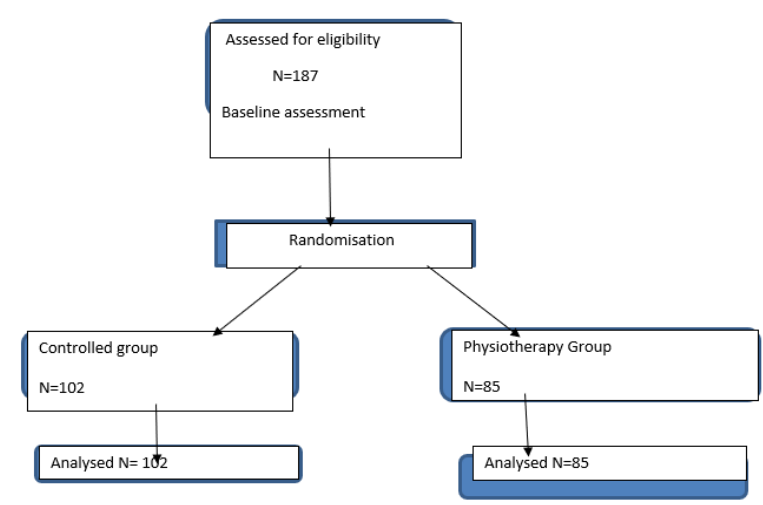


Data collection procedure: Cough severity index, MMRC grading, Respiration rate and peripheral blood saturation were measured. Respiration rate was measured by the trained clinician on lying down supine position with distraction clinician tool. A pulse oximeter was used for the measurement of peripheral blood saturation on subsequent days. The pulse oximeter was standardized with arterial blood gas. Patient readings had been noted on Day 1,5 , $10,15,20$. The respiratory rate was counted on Day $1,5,10,15,20$.

Scoring system: Patients were assessed on basis of parameters e.g. Clinical symptoms-cough, SOB, Spo2, Duration of hospital stay.

Simplified cough score: The severity of cough was assessed according to Simplified cough score:

\begin{tabular}{|l|l|l|}
\hline Score & \multicolumn{1}{|c|}{ Daytime } & \multicolumn{1}{|c|}{ Night time } \\
\hline 0 & No cough & No cough \\
\hline 1 & $\begin{array}{l}\text { Transient cough } \\
\text { occasionally during the } \\
\text { daytime }\end{array}$ & $\begin{array}{l}\text { Transient cough before sleep or } \\
\text { occasional cough during the night }\end{array}$ \\
\hline 2 & $\begin{array}{l}\text { Frequent cough mildly } \\
\text { affecting daily life }\end{array}$ & Cough mildly affecting night sleep \\
\hline 3 & $\begin{array}{l}\text { Frequent cough severely } \\
\text { affecting daily life }\end{array}$ & Cough severely affecting night sleep \\
\hline
\end{tabular}

MMRC Dyspnoea scale: Breathlessness was assessed and graded according to the MMRC Dyspnoea scale [4]:

\begin{tabular}{|l|l|}
\hline Grade & \multicolumn{1}{|c|}{ Description } \\
\hline 0 & No trouble by breathlessness except on strenuous exercises \\
\hline 1 & Short of breath when hurrying or walking up a slight hill \\
\hline 2 & $\begin{array}{l}\text { Walks slower than contemporaries on the level or has to stop for } \\
\text { breath when walking at their own pace }\end{array}$ \\
\hline 3 & $\begin{array}{l}\text { Stops for breath after walking } 100 \mathrm{~m} \text { or after few minutes on the } \\
\text { level }\end{array}$ \\
\hline
\end{tabular}

4 Too breathless to leave the house or breathless when dressing or undressing

Ethical consideration \& permission: A permission was obtained to conduct the study from administrative authorities of the institution.

Statistical analysis: Observation data were collected for variables of interest. The baseline characteristics of the control and physiotherapy group compared with independent t-tests to determine the predictors. Alpha was set at 0.05 for statically significant predictors. Difference between control and physiotherapy groups and within in group change were tested with independent t-tests with a significant level $p$-value $<0.05$.

\section{Result}

A total of 187 were recruited and a baseline assessment is done. Eighty-five of them were in the control group and 102 were in the control group. Adherence to exercise and attendance was monitored. The completion rate of the study was $100 \%$. The difference between the pre and postexercise intervention data collected. Mean Cough severity index, mean MMRC, mean respiration rate and mean peripheral blood saturation summarized in table no. 3. There was a significant difference in mean MMRC, mean respiration rate and peripheral blood saturation between the two groups. The physiotherapy group showed more improvement in peripheral blood saturation $(89.10+/-13.4$ vs $95.37+/-16.7, \mathrm{p}$ value $<0.05)$ and mean MMRC grade $(3.56+/-1.26$ vs $1.86+/-1.16$, $\mathrm{p}$-value $<0.05)$. Although there was no significant improvement in the cough severity index.

Table-1: Representing Baseline characteristics

\begin{tabular}{|l|l|l|l|l|l|}
\hline Sr. no. & \multicolumn{1}{|c|}{ Variables } & Total=187 & \multicolumn{1}{|c|}{ Physiotherapy group $=\mathbf{8 5}$} & \multicolumn{1}{c|}{ Control group= 102 } & P value \\
\hline 1 & Age (mean) & 41.8 & 42.2 & 43.5 & 0.42 \\
\hline 2 & Gender & 131 & 58 & 73 & 0.31 \\
& Male & 56 & 27 & 29 & \\
& Female & & & 15 & 0.73 \\
\hline 4 & *Underlying lung disease, & 38 & 23 & 11 & 0.53 \\
\hline
\end{tabular}

*These patient were on medication with wellcontrolled hypertension and diabetic Mellitus. These patients were reviewed by the specialist medical team for monitoring of underlying disease. Value is
Table no 1 is showing, the mean age of patients was 41.8 years. Out of 187 patients 131 were male and the remaining 56 were female. 58 male patients were in the physiotherapy group similarly 73 
Out of total female patients (56), 27 were in the physiotherapy group and 29 patients were in the control group. Including other comorbidities hypertension was present in a total of 38 patients, among them 23 patients were in the physiotherapy group and 25 patients were in the control group, similarly diabetes mellitus was present in a total of 29 patients, among them 18 patients were in the physiotherapy group and 11 patients were in the control group.

Table-2: Comparison of duration of hospital stay and clinical resolution in physiotherapy and control groups.

\begin{tabular}{|l|c|c|l|}
\hline & $\begin{array}{c}\text { Physiotherapy } \\
\text { group }\end{array}$ & $\begin{array}{c}\text { Control } \\
\text { group }\end{array}$ & P-value \\
\hline $\begin{array}{l}\text { Duration of hospital stays (mean } \\
\text { days) }\end{array}$ & $13.42+/-2.06$ & $19.36+/-3.08$ & 0.026 \\
\hline
\end{tabular}

*Time to clinical resolution (mean days)

respiratory work/cough

\begin{tabular}{l|l|l|}
$9.56+/-1$ & $16.67+/-2$ & 0.04
\end{tabular} .86

.34

Values are mean with standard deviation and statistically significant at $p$-value $<0.05$

*Clinical resolution defined that no respiratory symptom like cough, fever, breathlessness absent last three days. The mean duration of hospital stay was significantly lesser in the physiotherapy group as compared to the control group (13.42 days and 19.36 days respectively). Resolution of cough and respiratory work was significantly faster in the physiotherapy group than in the control group (9.56 days and 16.67 days respectively).

Table-3: Comparison of variables in physiotherapy and control groups.

\begin{tabular}{|c|c|c|c|c|c|c|c|c|c|c|c|}
\hline Parameter & & day & & day & 10t & h day & 15t & th day & 20tt & h day & P- \\
\hline Group & physio & control & physio & control & physio & control & $\begin{array}{l}\text { Physio } \\
\text { Group }\end{array}$ & $\begin{array}{l}\text { Control } \\
\text { group }\end{array}$ & $\begin{array}{l}\text { Physio } \\
\text { Group }\end{array}$ & $\begin{array}{l}\text { Control } \\
\text { group }\end{array}$ & value \\
\hline *Cough severity (Mean) & 2 & 2 & 2 & 2 & 1 & 2 & 0 & 1 & 0 & 0 & 0.34 \\
\hline *Breathlessness (Mean grade) & $\begin{array}{l}3.56 \\
+/-1.26\end{array}$ & $\begin{array}{l}3.60 \\
+/-1.36\end{array}$ & $\begin{array}{l}3.08 \\
+/-1.24\end{array}$ & $\begin{array}{l}3.18 \\
+/-1.32\end{array}$ & $\begin{array}{l}2.67 \\
+/-1.22\end{array}$ & $\begin{array}{l}2.86 \\
+/-1.29\end{array}$ & $\begin{array}{l}2.14 \\
+/-1.24\end{array}$ & $\begin{array}{l}2.27+/-1.2 \\
3\end{array}$ & $\begin{array}{l}1.86 \\
+/-1.16\end{array}$ & $2.10+/-1.1$ & 0.067 \\
\hline $\begin{array}{l}\text { *Peripheral oxygen saturation } \\
(\text { mean \%) }\end{array}$ & $\begin{array}{l}89.10 \\
+/-13.4\end{array}$ & $\begin{array}{l}89.23 \\
+/-13.2\end{array}$ & $\begin{array}{l}90.56 \\
+/-14.3\end{array}$ & $\begin{array}{l}90.12 \\
+/-13.7\end{array}$ & $\begin{array}{l}93.34+/-1 \\
5.7\end{array}$ & $\begin{array}{l}91.93 \\
+/-13.6\end{array}$ & $\begin{array}{l}94.91+/-1 \\
6.3\end{array}$ & $\begin{array}{l}93.46 \\
+/-14.9\end{array}$ & $\begin{array}{l}95.37+/-1 \\
6.7\end{array}$ & $\begin{array}{l}94.78+/-1 \\
5.2\end{array}$ & 0.034 \\
\hline $\begin{array}{l}\text { *Respiratory rate (mean) } \\
\text { (breaths/min) }\end{array}$ & $\begin{array}{l}28.43 \\
+/-6.3\end{array}$ & $\begin{array}{l}28.74+/- \\
6.3\end{array}$ & $\begin{array}{l}23.54 \\
+/-6.2\end{array}$ & $\mid \begin{array}{l}23.83 \\
+/-6.2\end{array}$ & $\begin{array}{l}21.23 \\
+/-5.9\end{array}$ & $\mid \begin{array}{l}21.37 \\
+/-6.0\end{array}$ & $\begin{array}{l}21.04+/-5 \\
.9\end{array}$ & $21.43+/-6$ & $\begin{array}{l}19.56+/-5 . \\
5\end{array}$ & $20.26+/-5$ & 0.073 \\
\hline
\end{tabular}

These data were mean value with standard deviation. Statistically significant at p-value $<0.05$ )

Table 3 is showing the comparison of variables among the two groups. All patients had a score of 2 coughs on admission in both groups then the mean severity of cough was the same till 9th day then it was decreased to score 1 on day 10 in physiotherapy group but mean severity was as same as on admission day in the control group. On day 15 there was the total resolution of cough in the physiotherapy group but there was a fall in mean severity of cough but not up to total resolution in the control group. On day 20 there was the total resolution of cough occurred in both groups.

All patients had breathlessness of mean grade 3.56 $+/-1.26$ and $3.60+/-1.36$ respectively in physiotherapy and control groups. With time fall in the severity of breathlessness occurred in both groups and on day 20th the mean severity of
Breathlessness was minimum in the physiotherapy group $(1.86+/-1.16)$. The mean Spo2 was below $90 \%$ in both groups at the time of admission, which was gradually increased with a stay in hospital. Increment in mean $\mathrm{Spo} 2$ was more in the physiotherapy group and it was maximum in the physiotherapy group on Day 20 (95.37+/-16.7).

At the time of admission all patients were tachypnea, the mean respiratory rate was 28.43 $+/-6.3$ and $28.74+/-6.3$ breaths/min in physiotherapy and control group respectively. The work of breathing of patients was decreased so respiratory rate was also decreased in both groups and it was minimum $(19.56+/-5.5)$ in the physiotherapy group on Day 20.

\section{Discussion}

The purpose of this study was to observe the role of physiotherapy in COVID-19 disease. 
Respiratory physiotherapy is one therapeutic approach for symptom alleviation in various respiratory disease. Breathing control exercise combine with a multidisciplinary approach could enhance total lung capacity inpatient with influenzarelated ARDS disease [5]. This study showed the severity of cough had been decreased earlier in the physiotherapy group than in the control group. A similar finding was observed by O'reilly $\mathrm{N}$ et al. in their study [6]. This could be due to interventions used in chest physiotherapy eg. Chest percussion, change in the positioning of patients and breathing exercises.

These respiratory exercises have a role in clearing the airway and thus decreases cough severity. This study was showed that the severity of breathlessness was decreased in all patients of both groups. The difference in resolution of breathlessness was more in the physiotherapy group. It was observed that Due to decrease in breathing-related effort and work among the physiotherapy group lead to a decrement in the MMRC breathlessness scale and severity of breathlessness. Chest physiotherapy technique help in breathing-related work reduction and alveolar recruitment. It might help alleviate the severity of breathlessness [7].

We had also observed that decrement of respiration rate was higher in the physiotherapy group than in the control group. This study had shown that oxygen requirement was also more decreased in the physiotherapy group than in the control group. Several randomized control trial demonstrated that the effect of respiratory physiotherapy on a patient admitted with the acute viral disease lead to enhancement of Spo2 and improvement of respiration rate [3]. [8].It indicated that physiotherapy has indirectly overcome the work of breathing and decrease the requirement of oxygen. [9]. It was observed that our study have baseline mean Spo2 of patients were below $90 \%$ and patients were hypoxic on admission and physiotherapy group showed remarkable improvement in oxygen saturation.

It was observed that Increment in oxygen saturation among patients was earlier in the physiotherapy group than the control group. Earlier improvement of oxygen saturation, decrement of oxygen requirement and earlier settlement of respiration rates was lead to alleviation of the severity of disease and early recovery of patients.
SARS-Co-V-1 is an earlier strain found in china in 2003. SARS-Co-V-2 has shown remarkable similarity with SARS-Co-V-1 in receptor and structure [10]. Earlier studies in china demonstrated that chest physiotherapy helpful in reducing hospital stay in SARS-Co-V-1 related disease [11]. Lau et al showed that chest exercise improves muscle performance and cardiorespiratory function in SARS-Co-V-1 disease [12]. A similar effect was observed in our study.

Strengths and limitations: This paper has several strengths. It provides clinical guidance for care of covid-19 patients to physiotherapists. It helps physicians in the management of patients having compromised lung functions. It guided for weaning inpatient of noninvasive ventilation. There are also some limitations. The natural history of covid-19 is not clearly defined yet. Some change in clinical guidance may be expected. Recommendation for best evidence needed multicenter and large study group. Long term follows required of survivors group for application of recommendation.

\section{Conclusion}

This study concluded that physiotherapy has a beneficial role in the early recovery of COVID-19 patients and duration of stay in hospital. Physiotherapy interventions can resolve clinical symptoms and hypoxemia earlier.

\section{Contribution by authors}

Dr. Sanjay Kumar Bharty had designed the study protocol, collected and analysed data of the study.

Dr. Prof. Jitendra Kishore Bhargav had helped in the design study protocol and analysis of data.

Dr. Brahma Prakash had collected data and assembled data.

Dr. Vikas Patel has compiled data.

Dr. Avinash Jain had helped in manuscripts writing and analysis of data.

Dr. Sumit Khatri had prepared manuscripts and supported data compilation.

\section{What does the study add to the existing knowledge?}

This study has demonstrated the significance of physiotherapy in covid-19 the disease. 
Respiratory physiotherapy can cause an earlier improvement of symptoms and decrease hospital stay. It will lead to a decrement in resources requirement. This type of study showed that Respiratory physiotherapy is one of the therapeutic approaches for the management of covid-19 disease and post covid illness.

\section{Reference}

01. The Australian and New Zealand Intensive Care Society. The Australian and New Zealand Intensive Care Society (ANZICS) COVID-19 Guidelines Version 1. 2020. [Crossref][PubMed][Google Scholar]

02. Cabillic M, Gouilly P, Reychler G. Techniques manuelles de drainage bronchique des adultes et adolescents- quel niveau de preuve?, [Manual airway clearance techniques in adults and adolescents- What level of evidence?]. Rev Mal Respir. 2018;35(5)495-520. doi: 10.1016/j.rmr. 2015.12.004 [Crossref][PubMed][Google Scholar]

03. Hsieh MJ, Lee WC, Cho HY, Wu MF, Hu HC, Kao KC, Chen NH, Tsai YH, Huang CC. Recovery of pulmonary functions, exercise capacity, and quality of life after pulmonary rehabilitation in survivors of ARDS due to severe influenza A (H1N1) pneumonitis. Influenza Other Respir Viruses. 2018 Sep;12(5)643-648. doi: 10.1111/irv.12566 [Crossref][PubMed][Google Scholar]

04. Stenton C. The MRC breathlessness scale. Occup Med (Lond). 2008 May;58(3)226-7. doi: 10.1093/occmed/kqm162 [Crossref][PubMed] [Google Scholar]

05. Gomes GR, Donadio MVF. Effects of the use of respiratory physiotherapy in children admitted with acute viral bronchiolitis. Arch Pediatr. 2018;25 (6)394-398. doi: 10.1016/j.arcped.2018.06.004 [Crossref][PubMed][Google Scholar]

06. O'Reilly $\mathrm{N}$ et al. physiopedia[Online]; Respiratory Management of COVID-19. 2020. 26. 11.2020: doi: 10.1016/j.jphys.2020.03.011 [Crossref][PubMed][Google Scholar]

07. Zhu Y, Wang Z, Zhou Y, Onoda K, Maruyama H, $\mathrm{Hu} C$, et al. Summary of respiratory rehabilitation and physical therapy guidelines for patients with COVID-19 based on recommendations of World Confederation for Physical Therapy and National Association of Physical Therapy. J Phys Ther Sci. 2020;32(8)545-549. doi: 10.1589/jpts.32.545 [Crossref][PubMed][Google Scholar]
08. Huang C, Wang Y, Li X, Ren L, Zhao J, Hu Y, et al. Clinical features of patients infected with 2019 novel coronavirus in Wuhan, China. Lancet. 2020 Feb 15;395(10223)497-506. doi: 10.1016/S01406736(20)30183-5 [Crossref][PubMed][Google Scholar]

09. Greenhalgh T, Knight M, A'Court C, Buxton M, Husain L. Management of post-acute covid-19 in primary care. BMJ. 2020 Aug 11;370;m3026. doi: 10.1136/bmj.m3026 [Crossref][PubMed][Google Scholar]

10. Lee $N$, Hui $D$, Wu $A$, Chan $P$, Cameron $P$, Joynt $\mathrm{GM}$,et al. A major outbreak of severe acute respiratory syndrome in Hong Kong. N Engl J Med. 2003 May 15;348(20)1986-94. doi: 10.1056/NEJMoa030685 [Crossref][PubMed][Google Scholar]

11. Thomas $\mathrm{P}$, Baldwin C, Bissett B, Boden I, Gosselink R, Granger CL, et al. Physiotherapy management for COVID-19 in the acute hospital setting- clinical practice recommendations. J Physiother. 2020 Apr;66(2)73-82. doi: 10.1016/j.jphys.2020.03.011 [Crossref][PubMed] [Google Scholar]

12. Lau HM, Ng GY, Jones AY, Lee EW, Siu EH, Hui DS. A randomised controlled trial of the effectiveness of an exercise training program in patients recovering from severe acute respiratory syndrome. Aust J Physiother. 2005;51(4)213-9. doi: 10.1016/s0004-9514(05)70002-7 [Crossref] [PubMed][Google Scholar] 